\title{
EFEKTIVITAS PENGGUNAAN MEDIA PEMBELAJARAN HURUF HIJAIYAH BERBASIS MULTIMEDIA TERHADAP KEMAMPUAN MEMBACA AL-QURAN PESERTA DIDIK KELAS III SD NEGERI 1 PAREPARE
}

\author{
Wahyuni Munir \\ MA DDI Taqwaq Parepare \\ Email: wahyuni@stainparepare.c.id
}

\begin{abstract}
This study discusses the Effectiveness of Using Hijaiyah Letters Learning Media Based Multimedia toward al-Quran reading Ability of the third grade students in SD Negeri 1 Parepare. The purpose of this thesis to know the al-Quran reading ability of students before and after Hijaiyah Letters Learning Media based Multimedia applied and then to know the the Effectiveness of Using Hijaiyah Letters Learning Media Based Multimedia toward al-Quran reading Ability of the third grade students in SD Negeri 1 Parepare.This type of research is a trueexperimental research. The True-experimental research design used is Pre-Test and Post-Test Control Group Design, which means that there are two groups selected at random, then given pre test to know the initial state is there any difference between the experimental group and the control group. Data source is all students of the third grade students in SD Negeri 1 Parepare that is class III a and III b; Research instruments are Observation Sheet, reading test of Quran and Student Response Questionnaire; Data collection techniques are Observation, Test, and Questionnaire Technique; Processing Technique and analysis data includes Descriptive Statistics and Infrensial Statistics Analysis which includes Normality Test, Homogeneity Test, and Hypothesis Testing. The results of this research are: (1) The students of the experimental class and the control class have the ability to read al-Quran before being given treatment using Hijaiyah Letters Learning Media Based Multimedia. Both fall into the category quite smoothly. Then, al-Quran reading ability of experimental class after being treated better than the results of post-test control class, where the average result of the experimental class is 74.78 while the control class is 63.19 and belong to the category quite smoothly (2) The use of Hijaiyah Letters Learning Media Based Multimedia, proved to be effective can improve students' reading ability of the Quran. This result is proved by the increase of al-Quran reading ability, students activity during learning is good and student's response to learning activity is positive.
\end{abstract}


Keywords: Hijaiyah Letters Learning Media, al-Quran Reading Ability

\begin{abstract}
ABSTRAK
Studi ini membahas tentang Efektifitas Penggunaan Media Pembelajaran Huruf Hijaiyah Berbasis Multimedia terhadap Kemampuan Membaca al-Quran Peserta Didik Kelas III SD Negeri 1 Parepare.Adapun tujuan penelitian tesis ini adalah untuk mengetahui kemampuan membaca al-Quran peserta sebelum dan sesudah diterapkan media pembelajaran huruf hijaiyah berbasis multimedia dan untuk mengetahui keefektifan penggunaan media pembelajaran huruf hijaiyah berbasis multimedia terhadap kemampuan membaca al-Quran peserta didik SD Negeri 1 Parepare.Jenis penelitian ini adalah penelitian True Eksperimental. Desain penelitian True eksperimental yang digunakan adalah Pre-Test and Post-Test Control Group Design, yang berarti dimana terdapat dua kelompok yang dipilih secara acak, kemudian diberi pre test untuk mengetahui keadaan awal adakah perbedaan antara kelompok eksperimen dan kelompok kontrol. Sumber data adalah seluruh peserta didik kelas III di SD Negeri 1 Parepare yaitu kelas III a dan III b; instrumen penelitian adalah Lembar Observasi, Tes membaca al-Quran dan Angket.Respon Siswa; Teknik pengumpulan data adalah Teknik Observasi, Teknik Tes, dan Teknik Angket; Teknik pengelolaan dan analisis data yang meliputi Statistik Deskriptif dan Analisis Statistika Infrensial yang meliputi Uji Normalitas, Uji Homogenitas, dan Uji Hipotesis.Hasil Penelitian ini adalah (1) Para peserta didik kelas eksperimen dan kelas kontrol telah memiliki kemampuan membaca alQuran sebelum diberi perlakuan Penggunaan Media pembelajaran huruf hijaiyah berbasis multimedia.Keduanya tergolong dalam kategori cukup lancar. Kemudian kemampuan membaca al-Quran peserta didik kelas eksperimen setelah diberi perlakuan lebih baik dari hasil post-test kelas kontrol, dimana hasil rata-rata darikelas eksperimen adalah 74.78 sedangkan kelas kontrol adalah 63.19 dan tergolong dalam kategori cukup lancar.(2) Penggunaan Media pembelajaran huruf hijaiyah berbasis multimedia, terbukti efektif dapat meningkatkan kemampuan membaca al-Quran para siswa.Hasil ini dibuktikan dengan dengan peningkatan hasil kemampuan membaca al-Quran peserta didik, Aktivitas siswa selama pembelajaran baik serta respon siswa terhadap kegiatan pembelajaran positif.
\end{abstract}

Kata Kunci: Media Pembelajaran, Huruf Hijaiyah, Kemampuan membaca $\mathrm{Al}$ - Qur’an 


\section{PENDAHULUAN}

\section{Latar Belakang Masalah}

Pendidikan menjadi bagian penting dalam kehidupan manusia.Pendidikan merupakan upaya untuk mengembangkan segenap potensi manusia, sehingga dapat memberi manfaat dan memberi perubahan yang positif bagi bangsa, negara, dan agama. Hal ini terlihat jelas dalam Undang-Undang No. 20 tahun 2003 tentang sistem pendidikan Nasional, yang menyatakan bahwa:

Pendidikan nasional berfungsi mengembangkan kemampuan dan membentuk watak serta peradaban bangsa yang bermartabat dalam rangka mencerdaskan kehidupan bangsa, bertujuan untuk berkembangnyapotensi peserta didik agar menjadi manusia yang beriman dan bertakwa kepada Tuhan Yang Maha Esa, berakhlak mulia, sehat, berilmu, cakap, kreatif, mandiri, dan menjadi warga negara yang demokratis serta bertanggung jawab. ${ }^{1}$

Parepare sebagai kota yang mempunyai tujuan menjadi Mercusuar Pendidikan ingin mewujudkan pendidikan karakter dalam rangka melahirkan generasi yang unggul.Membangun pendidikan karakter yang kuat, harus diwujudkan melalui generasi yang tidak hanya pintar cerdas secara akademik, namun, juga memiliki akhlak mulia.Terlebih lagi identitas Parepare adalah kota Santri, kota Ulama, dan kota Religius.

Sejalan dengan itu Sekolah Dasar yang merupakan sebagai lembaga pendidikan dasar memiliki peran penting dalam mewujudkan tujuan pendidikan yangkeberadaannya merupakan fundamen dari pendidikan pada jenjang di atasnya. Pendidikan di Sekolah Dasar sangatlah penting bagi peserta didik karena hal inimerupakan dasar perkembangan pengetahuan yang diperoleh siswa.

Membaca merupakan tahap penting dalam proses perkembangan anak karena membaca merupakan gerbang pertama untuk menuju proses pembejaran yang lebih kompleks.

Salah satu wujud dari realisasi pengabdian manusia kepada Allah swt. yaitu dengan membaca dan mengamalkan isi kandungan al-Quran. Al-Quran adalah wahyu Allah atau firmanAllah untuk menjadi petunjuk dan pedoman bagi manusia yang beriman dan bertaqwa kepada Allah swt. Setiap umat Islam diwajibkan membaca kitab suci al-Quran dengan sebaik-baiknya dan tidak sedikit yang sudah mengkhatamkan al-Quranhingga beberapa kali, namun apakah mereka memahami isi al-Quranyang dibaca padahal seharusnya perlu dibaca juga terjemahannya untuk dipetik ilmunya dan diamalkan dalam kehidupan sehari-hari.

\footnotetext{
${ }^{1}$ Republik Indonesia, Undang-Undang Sistem Pendidikan Nasional No.20 Tahun 2003
} 
Ayat yang pertama diturunkan oleh Allah swt, adalah perintah membaca, sebagaimana dijelaskan pada Q.S.Al-Alaq (96) : 1-5

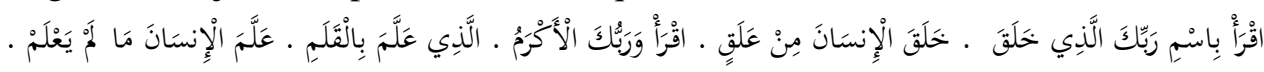

Terjemahannya:

(1). Bacalah dengan (menyebut) nama Tuhanmu yang Menciptakan, (2). Dia telah menciptakan manusia dari segumpal darah. (3). Bacalah, dan Tuhanmulah yang Maha pemurah, (4). yang mengajar (manusia) dengan perantaran kalam, (5). Dia mengajar kepada manusia apa yang tidak diketahuinya. ${ }^{2}$

Huruf hijaiyah merupakan salah satu materi pendidikan ilmu agama yang sangat penting untuk dipahami oleh manusia sebagai bekal hidup mereka untukmembaca, memahami dan mengamalkan kandungan al-Quran dimasa mendatang.

Hurufhijaiyah adalahaturan yang digunakan untuk membaca al-Quran maka orang yang tidak bisamembaca hijaiyah secara otomatis dia tidak bisa membaca alQuran padahalsebenarnya mereka sangat ingin bisa membaca al-Quran, karena alQuranadalah merupakan pedoman hidup atau kitab suci umatIslam.

Membaca al-Quran mempunyai banyak keutamaan. Sabda Nabi Muhammad saw yaitu:

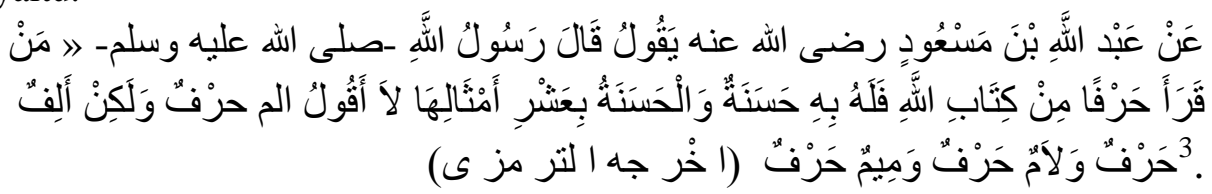

Dari Abdullah bin Mas'ud: Rasulullah bersabda: “Siapa yang membaca satu huruf dari al-Quran maka baginya satu kebaikan dengan bacaan tersebut, satu kebaikan dilipatkan menjadi 10 kebaikan semisalnya dan aku tidak mengatakan الم satu huruf akan tetapi alif satu huruf, lam satu huruf, dan mim satu huruf"

Hadits tersebut menjelaskan betapa mulianya orang yang membaca al-Quran sehingga Nabi menjelaskan tentang kebaikan dalam satu huruf akan mendapatkan satu kebaikan, dan satu kebaikan itu dilipatgandakan menjadi 10 (sepuluh) kebaikan.

Perkembangan dalam teknologi multimedia juga menjanjikan potensibesar dalam merubah cara seseorang belajar, cara memperoleh sumber untukbelajar dan

\footnotetext{
${ }^{2}$ Departemen Agama RI, Al-Quran dan Terjemahannya Special For Women, (Bandung: Sygma Publishing, 2010), h. 297

3 Imam Al hafidz Abil 'Ula muhammad "abdirrohman, Tuhfatulahwadzi bisyarhi Jami' Attirmidzi, juz 8 (Libanon, Beirut: Darul Kitab Al “ilmiah, 1683 H), hlm. 182
} 
cara beradaptasi dengan materi pembelajaran. Multimedia jugamenyediakan berbagai peluang kepada para pengajar untuk mengaplikasikanberbagai metode pengajaran dan memberikan pilihan pada peserta didik untuk menentukan teknik belajar yang sesuai dengan keinginan mereka, yaitu pengalaman, suasana belajar yang menarik dan berkesan.

Berdasarkan hasil observasiawal yang penelitilakukan di kelas IIISD Negeri 1 Parepare ditemukan berbagai permasalahan diantaranya: (1)Sebagian peserta didik telah mengenal huruf hijaiyahnamun masih membutuhkan bimbingan ketika membaca al-Quran(2) Sebagian peserta didik yang lain masih mengalami pengucapan huruf yang salah hal ini terlihat ketika salah satu anak diminta untuk menyebutkan beberapa huruf hijaiyah, (3) Proses pembelajaran guru menggunakan teknik menirukan secara lisan dengan tidak menggunakan media sehingga anakanak kurang mengingat kosakata yang telah disampaikan.

\section{Rumusan Masalah}

Berdasarkan latar belakang masalah di atas, masalah pokok yang akan di bahas dalam tesis ini adalah:

1. Apakah peserta didik Kelas III SD Negeri 1 Parepare memiliki kemampuan membaca al-Quran sebelum dan sesudah diterapkan media pembelajaran huruf hijaiyah berbasis multimedia?

2. Apakah penggunaan media pembelajaran huruf hijaiyah berbasis multimedia efektif terhadap kemampuan membaca al-Quranpeserta didik kelas III SD Negeri 1 Parepare?

\section{Landasan Teori}

\section{Penelitian yang Relevan}

Penelitian terkait yang membahas tentang media dalam pembelajaran dan kemampuan membaca al-Quran tentunya bukan merupakan penelitian yang baru dalam bidang pendidikan.

Siti Atika telah mengadakan penelitian dengan judul "Pemanfaatan Media Pembelajaran Berbasis Tekhnologi Multimedia dalam Peningkatan Minat Belajar Pendidikan Agama Islam pada Peserta didik SMA Negeri Se-Kota Palopo”. Hasil penelitian menunjukkan bahwa penggunaan media pembelajaran berbasis teknologi multimedia pada mata pelajaran Pendidikan Agama Islam pada SMA Negeri sekota Palopo relatif sedikit jika dibandingkan dengan tenaga pendidik Agama Islam yang cukup banyak. Jumlah Guru PAI di SMA Negeri Kota Palopo sebanyak 17 orang namun yang menggunakan hanya 3 orang $(17,64 \%)$. Terdapat pengaruh yang 
signifikan penggunaan media pembelajaran berbasis multimedia dalam pembelajaran Pendidikan Agama Islam terhadap minat belajar peserta didik. ${ }^{4}$

Penelitian Siti Atika sangat berbeda dengan penelitian yang dikembangkan dalam penelitian ini, baik konsep maupun metodologinya.Peneliti tersebut melihat pemanfaatan media pembelajaran berbasis tekhnologi multimedia dalam peningkatan minat belajar peserta didik, sedangkan dalam penelitian ini melihat keefektifan media pembelajaran huruf Hijaiyah berbasis multimedia terhadap kemampuan membaca al-Quran.Titik persamaannya terletak pada media pembelajaran berbasis multimedia.

\section{Analisis Teoretis Variabel}

\section{a. Efektifitas Pembelajaran}

Efektifitas berasal dari kata dasar efektif. Dalam kamus bahasa Indonesia, kata efektif mempunyai arti mempunyai efek, pengaruh atau akibat.

Suatu usaha dikatakan efektifitas apabila usaha itu telah mencapai tujuannya. Adapun efektifitas menurut Pringgodogjo adalah menunjukkan taraf tercapainya suatu efektif apabila itu mencapai tujuannya ${ }^{5}$.

Demikian dapat diambil kesimpulan mengenai efektifitas penggunaan media pembelajaran adalah suatu usaha, sejauh mana usaha dalam pembelajaran dengan menggunakan alat bantu (media) dalam pencapaian suatu tujuan yang telah direncanakan. Kriteria efektivitas yang digunakan dalam penelitian ini adalah apabila

tiga dari empat aspek yang meliputi: (1) Peningkatan Hasil Belajar; (2) aktivitas siswa selama pembelajaran baik; (3) respon siswa terhadap kegiatan pembelajaran positif; dan (4) Kemampuan guru dalam mengelola pembelajaran baik. Dengan syarat aspek ketuntasan belajar terpenuhi.

1) Hasil Belajar

Hasil belajar pada dasarnya adalah suatu kemampuan yang berupa keterampilan dan perilaku baru sebagai akibat latihan atau pengalaman.

2) Aktifitas Siswa

Proses belajar mengajar yang berkembang saat ini adalah pembelajaran"student centered" dimana siswalah yang dituntut untuk aktif dalam

${ }^{4}$ Siti Atika, Pemanfaatan Media Pembelajaran Berbasis Tekhnologi Multimedia dalam Peningkatan Minat Belajar Pendidikan Agama Islam pada Siswa SMA Negeri seKota Palopo, (Tesis Palopo: Institut Agama Islam Negeri (IAIN), 2016).

${ }^{5}$ Pringgodigjo,Ensiklopedia Umum, ( Yogyakarta: Yayasan Kanisius, 1973), h.29 
kegiatanbelajar mengajar. Ediyono menyatakan ada tujuhkadar keaktifan siswa dalam belajar, diantaranya yaitu: ${ }^{6}$

a) Partisipasi Siswa dalam menetapkan tujuan kegiatan pembelajaran

b) Partisipasi siswa dalam pelaksanaan pembelajaran, terutama interaksi antara siswa.

3) Respon Siswa

Respon siswa didefinisikan sebagai tanggapan siswa pada saat kegiatan belajar mengajar berlangsung.

\section{b. Media Pembelajaran Huruf Hijaiyah Berbasis Multimedia}

1) Media Pembelajaran

Kata media berasal dari bahasa Latin medius yang secara harfiah berarti 'tengah', perantara atau pengantar.Dalam bahasa Arab, media adalah perantara atau pengantar pesan dari pengirim kepada penerima pesan.

Adapun ciri-cirimedia antara lain:

a) Media pembelajaran memiliki pengertian fisik yang dewasa ini dikenal sebagai hardware (perangkat keras), yaitu sesuatu benda yang dapat dilihat, didengar, atau diraba dengan panca indera.

b) Media pembelajaran memiliki pengertian nonfisik yang dikenal sebagai software (perangkat lunak), yaitu kandungan pesan yang terdapat dalam perangkat keras yang merupakan isi yang ingin disampaikan kepada peserta didik.

2) Fungsi Media

Fungsi media pembelajaran cukup luas dan banyak. ${ }^{7}$ Namun secara lebih rinci dan utuh mediapembelajaran berfungsi untuk:

a) Meningkatkan efektifitas dan efesiensi pembelajaran

b) Meningkatkan gairah belajar anak didik

c) Meningkatkan minat dan motivasi belajar

3) Multimedia

a. Pengertian Multimedia

Multimedia meliputi berbagai media dalam satu software sehingga memudahkan pengajar untuk menyampaikan materi pemelajaran dan

\footnotetext{
${ }^{6}$ Gian Sri Wahyuni, Permainan kartu Tali Sebagai Media Pembelajaran pada pokok

Bahasan pencemaran Lingkungan di SMAN 2 Kediri Kelas II Semester 2, (Surabaya: UNESA, 2004),

Skripsi Tidak Diterbitkan, h.19.

${ }^{7}$ Musfiqon, h.35
} 
pembelajar merasa dilibatkan dalam proses belajar karena teknologi multimedia memberikan fasilitas berlakunya interaktif.

b. Kelebihan Media Berbasis Multimedia

Multimedia mempunyai beberapa kelebihan yang tidak dimiliki oleh media lain antara lain:

(1) Multimedia menyediakan proses interaktif dan memberikan kemudahan umpan balik.

(2) Multimedia memberikan kebebasan kepada pembelajar dalam menentukan topik proses belajar.

4) Aplikasi Huruf Hijaiyah Berbasis Multimedia

Hijaiyah Plus merupakan aplikasi interaktif baca tulis huruf hijaiyah untuk pemula yang mengenalkan semua hal yang berhubungan dengan huruf hijaiyah (huruf arab) yang dilengkapi juga dengan Makhraj dan Sifatul Huruf. Aplikasi ini dilengkapi dengan suara/audio untuk setiap bagiannya. ${ }^{8}$

Terdapat tanda baca seperti fathah, kasrah, sukun, dhommah, fahtahtain, kasrahtain, dhommahtain dan tasyid.Terdapat juga aturan mengenai tempat keluarnya huruf-huruf hijaiyah yaitu disebut dengan makhraj.dan aturan tentang penulisan huruf-huruf hijaiyah.Terdapat 29 huruf Hijaiyah yang masing-masing tersebar dalam 30 juz dan 114 surat di dalam Al-Quran.

\section{c. Kemampuan membaca al-Quran}

1) Al-Quran

Pengertian formal, al-Quran dapat dipahami sebagai sebuah kitab, atau lembaran kertas terjilid, dan tertulis di dalamnya dictum berbahasa Arab yang oleh Umat Islam dipercayai sebagai wahyu Allah.

2) Kemampuan Membaca

kemampuan membaca al-Quran adalah aktivitas kompleks yang mencakup fisik dan mental untuk digunakan melihat tulisan dan mengerti serta dapat melisankan apa yang tertulis di dalam al-Quran.

3) Kemampuan membaca al-Quran

Kemampuan membaca al-Quran yang dimaksud dalam tesis ini adalah:

a) Kemampuan membaca dengan makhraj

Secara bahasa, makhraj adalah مَوْضِعُ أْلَرُرُوجِ(tempat keluar), sedangkan menurut istilah, makhraj adalah:

\footnotetext{
${ }^{8}$ Abu Muazzam, Aplikasi Interaktif Hijaiyah Plus untuk Pemula, http://pustakaabumuazzam. blogspot.co.id/2014/05/aplikasi-interaktif-hijaiyah-plus.html, diakses 7 November 2016), 2016
} 


$$
\text { هُوَ إِسنمُ لِلْمَحَلِّ الَّذِى يُنْشَاًُ مِنْهُ الخْرَفُ. }
$$

"Suatu nama tempat, yang pada tempat tersebut huruf dibentuk atau diucapkan"

b) Kemampuan membaca dengan Harakat

Harakat (Arab: حركات, dibaca harakaat).Harakat digunakan untuk mempermudah caramelapazkan huruf dalam tiap ayat al Quran bagi seseorang yang baru belajar dan memahami atau mengenal tanda baca dalam membaca dan melapazkan al Quran.

\section{Kerangka Pikir Penelitian}

\section{Membaca al-Quran}

\begin{tabular}{|l|}
\hline Multimedia: \\
a.Text \\
b.Audio \\
c.Video \\
d.Animasi \\
gambar \\
\hline
\end{tabular}

Media Pembelajaran

Huruf Hijaivah

Berbasis Multimedia:

1. Pengenalan huruf hijaiyah

2. Tanda baca dalam al-Quran meliputi fathah, kasrah, dhammah, sukun, tasydid, madd, dan tanwin

3. Pengenalan huruf sambung

Kemampuan Membaca al-Quran:

1. Makharijul Huruf

2. Mengenal Harakat

Efektivitas:

1. Hasil Belajar

2. Aktivitas Siswa

3. Respon Siswa

\section{Peserta Didik}

Gambar 1. Kerangka Penelitian 


\section{Hipotesis}

Adapun hipotesis dalam penelitian ini adalah, "Penggunaan Media Pembelajaran Huruf Hijaiyah berbasis multimedia efektif terhadap kemampuan membaca al-Quran peserta didik kelas III SD Negeri 1 Parepare”. Dengan hipotesis statistiknya sebagai berikut:

Dimana:

$$
H_{0}: \mu_{1} \leq \mu_{2} \text { Lawan } H_{1}: \mu_{1} \leq \mu_{2}
$$

$\mathrm{H}_{\mathrm{o}}=$ Kemampuan membaca al-Quran peserta didik yang tidak menggunakan media pembelajaran huruf hijaiyah berbasis multimedia

$\mathrm{H}_{1}=$ Kemampuan membaca al-Quran peserta didik yang menggunakan media pembelajaran huruf hijaiyah berbasis multimedia

$\mu_{1}=$ Rata-rata Kemampuan membaca al-Quran peserta didik yang tidak menggunakan media pembelajaran huruf hijaiyah berbasis multimedia

$\mu_{2}=$ Rata-rata Kemampuan membaca al-Quran peserta didik yang menggunakan media pembelajaran huruf hijaiyah berbasis multimedia

\section{Metodologi Penelitian}

\section{Jenis dan Desain Penelitian}

Penelitian ini termasuk dalam penelitian kuantitatif dengan melakukan pengujian teori dan membangun fakta yang menunjukkan hubungan, efektifitas dan perbandingan antar variabel, memberikan deskripsi statistik, menaksir dan meramalkan hasilnya.

Jenis penelitian yang dilakukan adalah jenis penelitian true eksperimental (eksperimen yang sebenarnya).Dikatakan true eksperimental karena dalam desain ini, peneliti dapat mengontrol semua variabel yang mempengaruhi jalannya eksperimen.Ciri utama dari true eksperimental adalah bahwa, sampel yang digunakan untuk ekperimen maupun sebagai kelompok kontrol diambil secara random dari populasi tertentu.Jadi cirinya adalah adanya kelompok kontrol dan sampel dipilih secara random. ${ }^{9}$

Adapun desain penelitian true eksperimental yang digunakan adalah Pre testPost test Control Group Design. Hasil pretest yang baik bila nilai kelompok eksperimen tidak berbeda secara signifikan. ${ }^{10}$

Adapun desain penelitian yang digunakan seperti yang tampak pada tabel berikut :

\footnotetext{
${ }^{9}$ Sugiyono, Metode Penelitian Pendidikan, (Cet. XV; Bandung: ALFABETA, 2012), h. 112.

${ }^{10}$ Ibid, h. 113
} 


\section{Tabel 3.1 : Desain Penelitian}

Keterangan :

$\mathrm{X}_{1}$ : Perlakuan dengan menggunakan media pembelajaran huruf hijaiyah berbasis multimedia pada kelas eksperimen.

$\mathrm{T}_{1}$ : Kemampuan membaca al-Quran peserta didik kelas eksperimen sebelum perlakuan menggunakan media pembelajaran huruf hijaiyah berbasis mltimedia.

$\mathrm{T}_{2}$ : Kemampuan membaca al-Quran peserta didik kelas eksperimen sesudah perlakuan menggunakan media pembelajaran huruf hijaiyah berbasis multimedia

$\mathrm{T}_{3}$ : Kemampuan membaca al-Quran peserta didik kelas kontrol yang tidak diajar dengan penggunakan media pembelajaran huruf hijaiyah berbasis multimedia.

$\mathrm{T}_{4}$ : Kemampuan membaca al-Quran peserta didik kelas kontrol yang tidak diajar dengan penggunakan media pembelajaran huruf hijaiyah berbasis multimedia.

\section{Waktu dan Lokasi Penelitian}

Penelitian ini direncanakan dilaksanakan pada semester genap tahun ajaran 2016/2017 selama 2 bulan.Bertempat di SD Negeri 1 Parepare dengan alamat Jl. Matahari No. 5 Kelurahan Labukkang Kecamatan Ujung Kota Parepare.

\section{Populasi dan Sampel}

a. Populasi

Tabel 3.2 Populasi Penelitian

\begin{tabular}{|c|c|c|c|c|}
\hline \multirow{2}{*}{ No } & \multirow{2}{*}{ Kelas } & L & P & \multirow{2}{*}{ Total } \\
\cline { 3 - 4 } & & 10 & 17 & 27 \\
\hline 1 & Kontrol & 12 & 15 & 27 \\
\hline 2 & Eksperimen & 22 & 32 & 54 \\
\hline & Jumlah & &
\end{tabular}

Sumber: SD Negeri 1 Parepare 
b. Sampel

Tabel 3.3 Sampel Penelitian

\begin{tabular}{|c|c|c|c|}
\hline Kelompok & $\begin{array}{c}\text { Pre- } \\
\text { test }\end{array}$ & Perlakuan & Post-tes \\
\hline Eksperimen & $\mathrm{T}_{1}$ & $\mathrm{X}_{1}$ & $\mathrm{~T}_{2}$ \\
\hline Kontrol & $\mathrm{T}_{3}$ & & $\mathrm{~T}_{4}$ \\
\hline
\end{tabular}

\begin{tabular}{|c|c|c|c|}
\hline No & Kelas & Jumlah Populasi & Jumlah Sampel \\
\hline 1 & Kontrol & 27 & 27 \\
\hline 2 & Eksperimen & 27 & 27 \\
\hline \multicolumn{2}{|c|}{ Jumlah } & 54 & 54 \\
\hline
\end{tabular}

Sumber: SD Negeri 1 Parepare

\section{Metode Pengumpulan Data}

Penelitian ini menggunakan metode observasi dan metode tes untuk memperoleh data, yakni :
a Teknik Observasi
b Teknik Tes
a. Teknik Angket

\section{Instrumen Penelitian}

Instrumen yang digunakan dalam penelitian ini adalah tes kemampuan membaca al-Quran, lembar observasi aktivitas peserta didik.
a. Tes Kemampuan Membaca al-Quran
b. Lembar Observasi
c. Angket Respon Siswa

\section{Teknik Pengolahan dan Analisis Data}

Data yang diperoleh dari hasil penelitian ini dianalisis dengan dua teknik analisis statistika, yaitu :

1. Statistik deskriptif

2. Analisis Statistika Inferensial

a) Uji Normalitas

b) Uji Homogenitas

c) Uji Kesamaan Dua Rata-Rata Hasil Pre-tes Kelas Kontrol dan Pre-tes Kelas Eksperimen sebelum Perlakuan 


\section{Prosedur Eksperimen}

Penggunaan media pembelajaran Huruf Hijaiyyah berbasis multimedia dilakukan sebanyak 3 kali pertemuan setelah sebelumnya dilakukan pre test dan setelah perlakuan sebanyak tiga kali kemudian diadakan post test.

\section{PEMBAHASAN}

\section{Hasil Analisis Deskriptif}

a. Hasil Analisis Statistik Deskriptif Pre-Test Kelas Control

Tabel 4.2: Persentase Kategori Perolehan Hasil Pre-Test KelasKontrol

\begin{tabular}{|c|c|c|c|c|}
\hline No. & Interval Skor & Interpretasi & Frekuensi & Persentasi (\%) \\
\hline 1 & $80<x \leq 100$ & Sangat lancer & 2 & $7,4 \%$ \\
\hline 2 & $60<x \leq 79$ & Cukup lancer & 15 & $55,6 \%$ \\
\hline 3 & $40<x \leq 59$ & Kurang lancer & 5 & $18,5 \%$ \\
\hline 4 & $\leq 39$ & $\begin{array}{c}\text { Sangat kurang } \\
\text { lancer }\end{array}$ & 5 & $18,5 \%$ \\
\hline \multicolumn{3}{|c|}{ Jumlah } & 27 & 100 \\
\hline
\end{tabular}

b. Hasil Analisis Statistik Deskriptif Post-Test Kelas Kontrol

Tabel 4.4: Persentase Kategori Perolehan Hasil Post-Test Kelas Kontrol

\begin{tabular}{|c|c|c|c|c|}
\hline No. & Interval Skor & Interpretasi & Frekuensi & Persentasi (\%) \\
\hline 1 & $80<x \leq 100$ & Sangat lancar & 3 & $11,1 \%$ \\
\hline 2 & $60<x \leq 79$ & Cukup lancar & 16 & $59,3 \%$ \\
\hline 3 & $40<x \leq 59$ & Kurang lancar & 3 & $11,1 \%$ \\
\hline 4 & $\leq 39$ & $\begin{array}{c}\text { Sangat kurang } \\
\text { lancar }\end{array}$ & 5 & $18,5 \%$ \\
\hline \multicolumn{3}{|c|}{ Jumlah } & 27 & $100 \%$ \\
\hline
\end{tabular}

c. Hasil Analisis Statistik Deskriptif Pre-Test Kelas Eksperimen

Tabel 4.6: Persentase Kategori Perolehan Hasil Pre-Test Kelas Eksperimen

\begin{tabular}{|c|c|c|c|c|}
\hline No. & Interval Skor & Interpretasi & Frekuensi & Persentasi (\%) \\
\hline 1 & $80<x \leq 100$ & Sangat lancar & 4 & $14,8 \%$ \\
\hline 2 & $60<x \leq 79$ & Cukup lancar & 14 & $51,9 \%$ \\
\hline 3 & $40<x \leq 59$ & Kurang lancar & 3 & $11,1 \%$ \\
\hline 4 & $\leq 39$ & $\begin{array}{c}\text { Sangat kurang } \\
\text { lancar }\end{array}$ & 6 & $22,2 \%$ \\
\hline \multicolumn{3}{|c|}{ Jumlah } & 27 & $100 \%$ \\
\hline
\end{tabular}


d. Hasil Analisis Statistik Deskriptif Post-Test Kelas Eksperimen

Tabel 4.8: Persentase Kategori Perolehan Hasil Post-Test Kelas Eksperimen

\begin{tabular}{|c|c|c|c|c|}
\hline No. & Interval Skor & Interpretasi & Frekuensi & Persentasi (\%) \\
\hline 1 & $80<x \leq 100$ & Sangat lancar & 11 & 40,7 \\
\hline 2 & $60<x \leq 79$ & Cukup lancar & 12 & 44,4 \\
\hline 3 & $40<x \leq 59$ & Kurang lancar & 3 & 11,1 \\
\hline 4 & $\leq 39$ & $\begin{array}{c}\text { Sangat kurang } \\
\text { lancar }\end{array}$ & 1 & 3,7 \\
\hline \multicolumn{3}{|c|}{ Jumlah } & 27 & 100 \\
\hline
\end{tabular}

Tabel di atas diperoleh bahwa gambaran kemampuan membaca al-Quran siswa kelas eksperimen setelah menggunakan media pembelajaran huruf hijaiyah berbasis multimedia adalah siswa yang memperoleh skor yang sangat lancar sebanyak 11 siswa dengan persentase 40,7\%, sebanyak 12 siswa memperoleh skor cukup lancar dengan persentase $44,4 \%$, ada sebanyak 3 siswa memperoleh skor kurang lancar dengan persentase $11,1 \%$ skor ini tidak menunjukkan peningkatan karena skor persentasenya masih sama dengan hasil pre-test, hal ini disebabkan pada saat pemberian perlakuan siswa-siswa tersebut kurang fokus dengan materi pembelajaran yang diberikan, sering mengganggu teman-temannya ketika proses pembelajaran serta siswa-siswa tersebut sulit untuk menangkap pembelajaran dengan cepat. Kemudian ada sebanyak 1 siswa memperoleh skor sangat kurang lancar dengan persentasi 3,7\%. Dengan demikian dapat dapat disimpulkan bahwa skor kemampuan hasil belajar siswa yang diukur melalui hasil post-test untuk kelas eksperimen termasuk dalam kategori cukup lancar dengan frekuensi 12 siswa dan persentase 44,4\%. Ini berarti siswa sudah cukup lancar dalam membaca al-Quran dilihat dari segi bacaan kharakat, pengucapan huruf atau makhrijul huruf.

\section{Indeks Gain Kemampuan Membaca al Quran}

Rekapitulasi data rata-rata nilai pre-test post-test dan indeks gain kemampuan membaca Al-Quran siswa kelas III SD Negeri I Parepare kelas eksperimen dan kelas kontrol dapat dilihat pada tabel 4.9 di bawah ini

Tabel 4.9 Data Pre-test Post-Test dan Indeks Gain

Kemampuan MembacaAl- Quran

\begin{tabular}{|l|c|c|c|c|}
\hline \multicolumn{1}{|c|}{ Kelas } & $\begin{array}{c}\text { Rata- } \\
\text { Rata } \\
\text { Pretest }\end{array}$ & $\begin{array}{c}\text { Rata- } \\
\text { rata } \\
\text { Posttest }\end{array}$ & $\begin{array}{c}\text { Indeks } \\
\text { Gain }\end{array}$ & $\begin{array}{c}\text { Kategori } \\
\text { Indeks } \\
\text { Gain }\end{array}$ \\
\hline Kontrol & 57,67 & 63,19 & 0,13 & Rendah \\
\hline Eksperimen & 62,26 & 74,78 & 0,33 & Sedang \\
\hline
\end{tabular}




\section{Hasil Pengamatan Keterlaksanaan Pembelajaran}

Hasil pengamatan keterlaksanaan pembelajaran yang dimaksudkan dalam penelitian ini menggunakan observasi aktivitas siswa, untuk melihat pencapaian siswa dalam melaksanakan pembelajaran penggunaan Media Pembelajaran Huruf Hijaiyah berbasis Multimedia . Adapun hasil observasi aktivitas siswa sebagai berikut:

Tabel 4.10: Hasil Rekapitulasi dari Kedua Observer Tentang Aktivitas Siswa Menggunakan media pembelajaran huruf hijaiyah berbasis Multimedia

\begin{tabular}{|c|c|c|c|c|c|c|}
\hline \multirow{2}{*}{ No. } & \multirow{2}{*}{$\begin{array}{c}\text { Observer } \\
\text { ke }\end{array}$} & \multicolumn{3}{|c|}{\begin{tabular}{c}
\multicolumn{2}{|c|}{ Rekapitulasi } \\
Persentase
\end{tabular}} & $\begin{array}{c}\text { Total } \\
\text { (\%) }\end{array}$ & $\begin{array}{c}\text { Rata- } \\
\text { rata } \\
\text { (\%) }\end{array}$ \\
\cline { 3 - 7 } & & \multicolumn{2}{|c|}{ Pertemuan ke- } & & \\
\cline { 3 - 7 } & I & II & III & & \\
\hline 1. & $\begin{array}{c}\text { Observer } \\
1\end{array}$ & 64 & 73 & 89 & 226 & 75 \\
\hline 2. & $\begin{array}{c}\text { Observer } \\
2\end{array}$ & 62 & 70 & 85 & 217 & 72 \\
\hline \multicolumn{2}{|c|}{ Total (\%) } & $\mathbf{1 2 6}$ & $\mathbf{1 4 3}$ & $\mathbf{1 7 3}$ & & \\
\hline \multicolumn{2}{|c|}{ Rata-rata (\%) } & $\mathbf{6 3}$ & $\mathbf{7 1 , 5}$ & $\mathbf{8 6 , 5}$ & & $\mathbf{7 3 , 5}$ \\
\hline
\end{tabular}

Tabel di atas diperoleh kesimpulan bahwa persentase aktivitas siswa dengan menggunakan Media Pembelajaran Huruf Hijaiyah berbasis Multimedia adalah 73,5\%. Berdasarkan kriteria keberhasilan tindakan, aktivitas siswa ini tergolong kategori "Baik" dengan interval skor $61 \% \leq P \leq 80 \%$.

\section{Hasil Analisis Respon Siswa Terhadap Penggunaan Media Pembelajaran Huruf Hijaiyah Berbasis Multimedia}

Pengumpulan data melalui angket respon siswa maka diperoleh respon siswa terhadap pelaksanaan kegiatan pembelajaran.Pemberian angket ini diberikan kepada 27 siswa pada pertemuan terakhir setelah post-test. Adapun gambaran mengenai respon siswa tersebut dipaparkan sebagai berikut: 
Tabel 4.11: Hasil analisis Respon siswa terhadap Penggunaan Media Pembelajaran Huruf Hijaiyah berbasis Multimedia

\begin{tabular}{|c|c|c|c|c|c|}
\hline \multirow[t]{2}{*}{ NO } & \multirow[t]{2}{*}{ Aspek } & \multicolumn{2}{|c|}{ Siswa Menjawab } & \multicolumn{2}{|c|}{$\begin{array}{c}\text { Persentase Siswa } \\
\text { Menjawab }\end{array}$} \\
\hline & & Senang & Tidak & Senang & Tidak \\
\hline \multirow[t]{2}{*}{1.} & $\begin{array}{l}\text { Pendapat Siswa } \\
\text { dalam belajar } \\
\text { Membaca al- } \\
\text { Quran }\end{array}$ & 21 & 6 & 77,77 & 22,22 \\
\hline & & Baik & Tidak & Baik & Tidak \\
\hline 2. & $\begin{array}{l}\text { Tanggapan siswa } \\
\text { terhadap } \\
\text { penerapan Media } \\
\text { pembelajaran } \\
\text { Huruf Hijaiyah } \\
\text { berbasis } \\
\text { Multimedia }\end{array}$ & 24 & 3 & 88,88 & 22,22 \\
\hline & & Setuju & Tidak & Setuju & Tidak \\
\hline 3. & $\begin{array}{l}\text { Pendapat siswa } \\
\text { jika media } \\
\text { pembelajaran } \\
\text { huruf hijaiyah } \\
\text { berbasis } \\
\text { multimedia } \\
\text { diterapkan } \\
\text { disekolah. }\end{array}$ & 25 & 2 & 92,59 & 7,40 \\
\hline
\end{tabular}

Tabel hasil angket respon siswa menunjukkan bahwa 77,77\% siswa senang belajar membaca Al-Quran, dan 22,22\% siswa yg tidak senang. Selanjutnya, 88,88\% siswa menanggapi dengan baik media pembelajaran Huruf Hijaiyah berbasis Multimedia yang diterapkan sekarang, dan $11,11 \%$ siswa yang tidak. Kemudian, 92,59\% siswa yang setuju jika Media Pembelajaran Huruf Hijaiyah diterapkan disekolah, dan 7,40 siswa yang tidak setuju. Dari kesemua jawaban siswa tersebut, dikatakan bahwa respon siswa positif terhadap Media pembelajaran Huruf Hijaiyah berbasis Multimedia. 


\section{Analisis Statistik Inferensial}

\section{a. Uji Normalitas Data}

Pengujian normalitas data dalam penelitian ini dengan menggunakan bantuan analisis SPSS.20. Berdasarkan hasil analisis tersebut maka didapat kesimpulan sebagai berikut :

1) Uji Normalitas data Pre-Test Kelas Kontrol

Didapatkan nilai signifikansi $\mathrm{p}=0,057$, sehingga $\mathrm{p}>\alpha$, dimana taraf signifikasnsi $\alpha=0,05$. Dengan demikian sampel berasal dari populasi yang berdistribusi normal.(Lihat lampiran 1)

2) Uji Normalitas data Post-Test Kelas Kontrol

Didapatkan nilai signifikansi $\mathrm{p}=0,123$, sehingga $\mathrm{p}>\alpha$, dimana taraf signifikansi $\alpha=0,05$. Dengan demikian sampel berasal dari populasi yang berdistribusi normal.(Lihat lampiran 1)

3) Uji Normalitas data Pre-test kelas Eksperimen

Didapatkan nilai signifikansi $\mathrm{p}=0,053$, sehingga $\mathrm{p}>\alpha$, dimana taraf signifikasnsi $\alpha=0,05$. Dengan demikian sampel berasal dari populasi yang berdistribusi normal.(Lihat lampiran 2).

4) Uji Normalitas Data Post-Test Kelas Eksperimen

Didapatkan nilai signifikansi $\mathrm{p}=0,060$, sehingga $\mathrm{p}>\alpha$, dimana taraf signifikansi $\alpha=0,05$. Dengan demikian sampel berasal dari populasi yang berdistribusi normal.(Lihat lampiran 2).

\section{b. Uji Homogenitas}

1) Uji homogenitas hasil pre-test siswa kelas kontrol dan siswa kelas eksperimen

Berdasarkan uji homogenitas seperti pada lampiran 3 pada tabel Test of Homogenity of Variance, maka dari analisis SPSS.20 yang telah dilakukan diperoleh p-value $=0,356$. Karena $p_{\text {value }} \geq \alpha$, dengan taraf signifikansi $\alpha=0,05$, sehingga dapat dikatakan data siswa mempunyai varians yang homogen.

2) Uji homogenitas hasil post-test siswa kelas kontrol dan siswa kelas eksperimen

Berdasarkan uji homogenitas seperti pada lampiran 4 pada tabel Test of Homogenity of Variance, maka dari analisis SPSS.20 yang telah dilakukan diperoleh p-value $=0,778$.Karena $p_{\text {value }} \geq \alpha$, dengan taraf signifikansi $\quad \alpha=$ 0,005 , sehingga dapat dikatakan data siswa mempunyai varians yang homogen. 


\section{c. Uji Hipotesis}

Data hasil penelitian berdsitribusi normal dan bervarians homogen maka dilanjutkan dengan uji t. Berikut hasil uji coba hipotesisnya :

1) Analisis Kesamaan Dua Rata-rata pada Tahap Awal Sebelum Perlakuan.

Berdasarkan uji hipotesis seperti pada tabel Independent sample test lampiran 5, maka didapatkan nilai $\mathrm{p}=0,412$ dengan $\alpha=0,05$. Jika $p_{\text {value }} \geq \alpha$ maka $\mathrm{H}_{0}$ diterima. Sehingga dapat disimpulkan bahwa kemampuan membaca al-Quran siswa sebelum perlakuan yaitu kelas eksperimen dan kelas kontrol adalah sama atau tidak ada perbedaan.

2) Analisis kesamaan dua rata-rata pada tahap akhir setelah perlakuan.

Berdasarkan uji hipotesis seperti pada tabel Independent sample test lampiran 6, maka didapatkan nilai $\mathrm{p}=0,041$ dengan $\alpha=0,05$. Jika $p_{\text {value }} \leq \alpha$ maka $\mathrm{H}_{0}$ ditolak dan $\mathrm{H}_{1}$ diterima.Sehingga dapat disimpulkan bahwa kemampuan membaca al-Quran siswa setelah perlakuan yaitu hasil post-test kelas eksperimen lebih baik dari hasil post-test kelas kontrol.

\section{PEMBAHASAN}

Hasil analisis data yang telah dilakukan untuk mengetahui gambaran awal kemampuan membaca al-Quran para peserta didik sebelum di berikan perlakuan menunjukkan hasil yang diperoleh melalui pre-test perolehan skor rata-rata kemampuan membaca al-Quran untuk kelas kontrol yaitu 57.67, berada dalam kategori cukup lancar dengan frekuensi 15 siswa dengan persentase 55,6\%, yang dimana sebagian besar siswa sudah bagus dari segi pengucapan huruf atau makhrijul huruf dan mengenal harakat akan tetapi membacanya masih belum lancar. Begitupun dengan kelas Eksperimen kemampuan awal membaca alQurannya berada dalam kategori cukup lancar dengan frekuensi 14 siswa dan persentase $51,9 \%$ dengan skor rata-rata $(\mu)=62,26$ dari skor ideal 100 . Jadi bisa dipastikan masing-masing baik kelas kontrol maupun eksperimen telah memiliki kemampuan awal dalam membaca al-Quran sebelum dan sesudah diterapkan nya media pembelajaran Huruf Hijaiyah berbasis Multimedia.

Kemudian setelah pemberian perlakuan untuk kelas eksperimen dengan penggunaan media pembelajaran Huruf Hijaiyah berbasis multimedia diperoleh skor rata-rata sebesar 74.78 yang diukur melalui hasil post test dan berdasarkan skor kategorisasi hasil tes kemampuan membaca al-Quran termasuk dalam kategori cukup lancar dilihat dari pengucapan huruf atau makhrijul huruf dan mengenal harakat. Dengan frekuensi 12 siswa dengan persentase 44.4\%. Hal ini telah mengalami peningkatan kemampuan membaca al-Quran setelah diterapkan media pembelajaran huruf hijaiyah berbasis multimedia, hal ini bisa dibuktikan dengan 
peningkatan hasil rata-rata antara pre test dan post test dimana nilai rata-rata yang pada awalnya 62.26 menjadi 74.78 dan frekuensi siswa yang berada dalam kategori sangat lancar mengalami peningkatan yang dimana pada hasil pre-test hanya ada 4 siswa namun setelah post tes meningkat menjadi 11 siswa, para siswa ini dilihat dari segi bacaan sesuai kharakat, fasih dalam pengucapan huruf atau makhrijul huruf serta lancar dalam membaca.juga. Sedangkan untuk kelas kontrol yang menggunakan cara konvensional diperoleh skor rata-rata 63.19 dan berdasarkan nilai kategorisasi kemampuan membaca al-Quran termasuk dalam kategori cukup lancar dengan frekuensi 59.3\%.

Selain itu, untuk mengetahui keefektifan penggunaan media pembelajaran Huruf Hijaiyah berbasis multimedia pada kelas eksperimen dan penggunaan media pembelajaran konvensional juga digunakan perhitungan gain ternormalisasi. Hasil perhitungan tes dengan menggunakan gain ternormalisasi diperoleh nilai g untuk kelas kontrol adalah sebesar 0.13 sedangkan nilai g untuk kelas eksperimen adalah sebesar 0.33. Berdasarkan nilai g di atas terlihat bahwa hasil belajar kelas eksperimen lebih tinggi dibandingkan kelas kontrol.

Kesimpulan ini memperlihatkan bahwa hipotesis penelitian yang diajukan pada bagian awal penelitian ini terbukti dapat diterima secara empiris, terbukti dengan hasil Uji Hipotesis dimana H1 diterima dan H0 ditolak.Sehingga dapat disimpulkan bahwa kemampuan membaca al-Quran siswa setelah perlakuan yaitu hasil post-test kelas eksperimen lebih baik dari hasil post-test kelas kontrol.

Sedangkan hasil pengamatan keterlaksanaan pembelajaran dengan menggunakan observasi aktivitas siswa, untuk melihat pencapaian siswa dalam melaksanakan pembelajaran penggunaan Media Pembelajaran Huruf Hijaiyah berbasis Multimedia diperoleh kesimpulan bahwa persentase aktivitas siswa yang melaksanakan pembelajaran sesuai dengan rencana pembelajaran dengan baik yaitu diantaranya tidak melakukan pekerjaan lain yang menganggu proses belajar Huruf Hijaiyyah berbasis Multimedia, menyimak seluruh informasi yang disampaikan tentang pembelajaran huruf hijaiyyah berbasis multimedia, peserta didik terlibat aktif dalam kegiatan belajar, memberikan tanggapan terhadap materi yang disampaikan dan hal-hal positif lainnyaadalah 73,5\%. Berdasarkan kriteria keberhasilan tindakan, aktivitas siswa ini tergolong kategori "Baik" dengan interval skor $61 \% \leq P \leq 80 \%$.

Adapun hasil angket Respon siswa terhadap penggunaan Media Pembelajaran Huruf Hijaiyah berbasis Multimedia dimana Aspek pertanyaan yang diberikan adalah terkait tanggapan siswa mengenai pembelajaran membaca al-Quran, penggunaan Media Pembelajaran Huruf Hijaiyah berbasis Multimedia serta 
penerapan nya. Berdasarkan analisis yang telah dilakukan, para peserta didik merasa senang, setuju dan merespon dengan baik.

Hal ini berarti penggunaan media pembelajaran Huruf Hijaiyah berbasis multimedia terbukti efektif terhadap kemampuan membaca al-Quran siswa kelas III SD Negeri 1 Parepare hal ini berdasar Kriteria efektivitas yang digunakan dalam penelitian ini adalah apabila tiga aspek yang meliputi: (1) Peningkatan hasil belajar; (2) aktivitas siswa selama pembelajaran baik; (3) respon siswa terhadap kegiatan pembelajaran positif.

Perkembangan dalam teknologi multimedia juga menjanjikan potensibesar dalam merubah cara seseorang belajar, cara memperoleh sumber untukbelajar dan cara beradaptasi dengan materi pembelajaran. Multimedia jugamenyediakan berbagai peluang kepada para pengajar untuk mengaplikasikanberbagai metode pengajaran dan memberikan pilihan pada peserta didik untuk menentukan teknik belajar yang sesuai dengan keinginan mereka, yaitu pengalaman, suasana belajar yang menarik dan berkesan.

\section{SIMPULAN}

Penggunaan Media pembelajaran huruf hijaiyah berbasismultimedia, terbukti efektif meningkatkan kemampuan membaca al-Quran para siswa. Hasil ini dibuktikan dengan peningkatan hasil rata-rata antara pre test dan post test kelas eksperimen nilai rata-rata yang pada awalnya 62.26 menjadi 74.78 dan berada dalam kategori cukup lancar dilihat dari segi kharakat, pengucapan huruf atau makhrijul huruf.Sedangkan untuk kelas kontrol yang menggunakan cara konvensional diperoleh skor rata-rata 63.19 untuk hasil post test. Terlihat bahwa hasil belajar kelas eksperimen lebih tinggi dibandingkan kelas kontrol.Hal ini membuktikan bahwa hipotesis penelitian yang diajukan pada bagian awal penelitian ini terbukti dapat diterima secara empiris, terbukti dengan hasil Uji Hipotesis dimana H1 diterima dan H0 ditolak.

Hasil pengamatan keterlaksanaan pembelajaran dengan menggunakan observasi aktivitas siswadalam melaksanakan pembelajaran penggunaan Media Pembelajaran Huruf Hijaiyah berbasis Multimedia diperoleh kesimpulan bahwa persentase aktivitas siswa adalah 73,5\% dan berdasarkan kriteria keberhasilan tindakan, aktivitas siswa ini tergolong kategori "Baik".

Respon siswa positif terhadap penggunaan Media Pembelajaran Huruf Hijaiyah berbasis Multimedia yang telah diterapkan selama proses pembelajaran. 


\section{DAFTAR PUSTAKA}

Al Quran Al Karim.

Atika,Siti. 2016. Pemanfaatan Media Pembelajaran Berbasis Tekhnologi Multimedia dalam Peningkatan Minat Belajar Pendidikan Agama Islam pada Peserta didik SMA Negeri seKota Palopo, Tesis Palopo: Institut Agama Islam Negeri (IAIN).

Imam Al hafidz Abil 'Ula muhammad "abdirrohman.Tuhfatulahwadzi bisyarhi Jami’ Attirmidzi, juz 8 Libanon, Beirut: Darul Kitab Al “ilmiah, 1683 H.

Muazzam, Abu. Aplikasi Interaktif Hijaiyah Plus untuk Pemula, http://pustakaabumuazzam. blogspot.co.id/2014/05/aplikasi-interaktifhijaiyah-plus.html, diakses 7 November 2016.

Musfiqon. 1973. Pengembangan Media dan Sumber Pembelajaran, Jakarta: Prestasi Pustaka, 2012.

Pringgodigjo, Ensiklopedia Umum, Yogyakarta: Yayasan Kanisius.

Wahyuni,Gian Sri. 2004. Permainan kartu Tali Sebagai Media Pembelajaran pada pokok Bahasan pencemaran Lingkungan di SMAN 2 Kediri Kelas II Semester 2, Surabaya: UNESA, 